\title{
ARHGAP35 wt Allele
}

National Cancer Institute

\section{Source}

National Cancer Institute. ARHGAP35 wt Allele. NCI Thesaurus. Code C97269.

Human ARHGAP35 wild-type allele is located in the vicinity of 19q13.32 and is approximately $86 \mathrm{~kb}$ in length. This allele, which encodes Rho GT Pase-activating protein 35 , plays a role in both the negative regulation of glucocorticoid receptor gene transcription and the positive regulation of Rac GAP activity 